\title{
Challenges for Cruise Sustainable Development and Its Legal Response: The Case of China
}

\author{
Yanan $\mathrm{Yu}^{1}$ and Yude Shao ${ }^{2, *(1)}$ \\ 1 Law School, Qingdao University of Science and Technology, Qingdao 266061, China; yuyanan@qust.edu.cn \\ 2 College of Ocean Science and Engineering, Shandong University of Science and Technology, \\ Qingdao 266590, China \\ * Correspondence: shaoyude@sdust.edu.cn
}

check for

updates

Citation: Yu, Y.; Shao, Y. Challenges for Cruise Sustainable Development and Its Legal Response: The Case of China. Sustainability 2021, 13, 6118. https://doi.org/10.3390/su13116118

Academic Editor: Giovanni De Feo

Received: 22 April 2021

Accepted: 25 May 2021

Published: 28 May 2021

Publisher's Note: MDPI stays neutral with regard to jurisdictional claims in published maps and institutional affiliations.

Copyright: (c) 2021 by the authors. Licensee MDPI, Basel, Switzerland. This article is an open access article distributed under the terms and conditions of the Creative Commons Attribution (CC BY) license (https:// creativecommons.org/licenses/by/ $4.0 /)$.

\begin{abstract}
The cruise industry has become one of the fastest-growing segments of global tourism industry in recent years. Its growth has led to some concerns about its impact on the marine environment, as cruise ships cause no less pollution than regular ships. China's cruise industry began late but has achieved fast development. However, there are still many challenges related to China's environmental legislation, and there is no clear-cut legal framework for the environmental protection of cruise ships in the various regulations in China. The legal literature on this issue is insufficient, and this paper attempts to fill the gap. First, it provides an overview of the global cruise industry, including the basic situation of cruise pollution. Second, it briefly introduces the relevant international conventions, and Chinese laws and regulations. Third, it analyzes the recent environmental challenges that cruise ships have faced. The goal of this paper is to give a legal direction for how the cruise industry can grow in ways that are both sustainable and responsible.
\end{abstract}

Keywords: cruise ships; environmental pollution; sustainable development; legal response; China

\section{Introduction}

According to the Collins English Dictionary, a cruise is defined as "a trip by sea in a line for pleasure, usually calling at a number of ports." In addition to the traditional function of providing accommodation and transportation, cruise ships also provide tourists with pleasant and comfortable leisure activities [1]. Acting as "floating resorts", cruise ships apply comfortable and leisure trip along the coastal cities worldwide for tourists.

The global cruise industry has experienced rapid growth during the past decade, and it is now one of the world's most dynamic and fastest-growing industries [2]. Cruise products are becoming an attractive lifestyle for leisure [3], with passengers' numbers rising from 17.8 million in 2009 to 30 million in 2019 according to the Cruise Lines International Association (Figure 1) [4]. Even in 2020, it was widely believed in the cruise industry that the impact of the COVID-19 pandemic would be temporary and not alter the long-term positive trend of the global cruise market [5].

To make the industry more sustainable, cruise companies are expanding their operations into emerging markets, especially in Asia [6]. Since 2000, the cruise industry is growing rapidly in terms of the number of cruises, ports, and the size of ships in Asia [7]. Although China's cruise industry has only been developing for around two decades, it is now one of the major players in the cruise industry and most of Asia's passenger growth is due to China [8], accounting for $67.8 \%$ of the passenger volume in 2019 (Figure 2). The demand for tourism consumption has increased with the rapid growth of China's economy. With support from government policies, marine tourism products represented by the cruise tourism has become one of the main driving forces for China's sustained growth in tourism [9]. China's cruise passenger volume reached 4.15 million in 2019 [10]. By the end of 2019, there were over 20 cities across China had built or planned to build cruise 
terminals. The total cruise ports of call in China increased four-fold in 10 years, as shown in Figure 3.

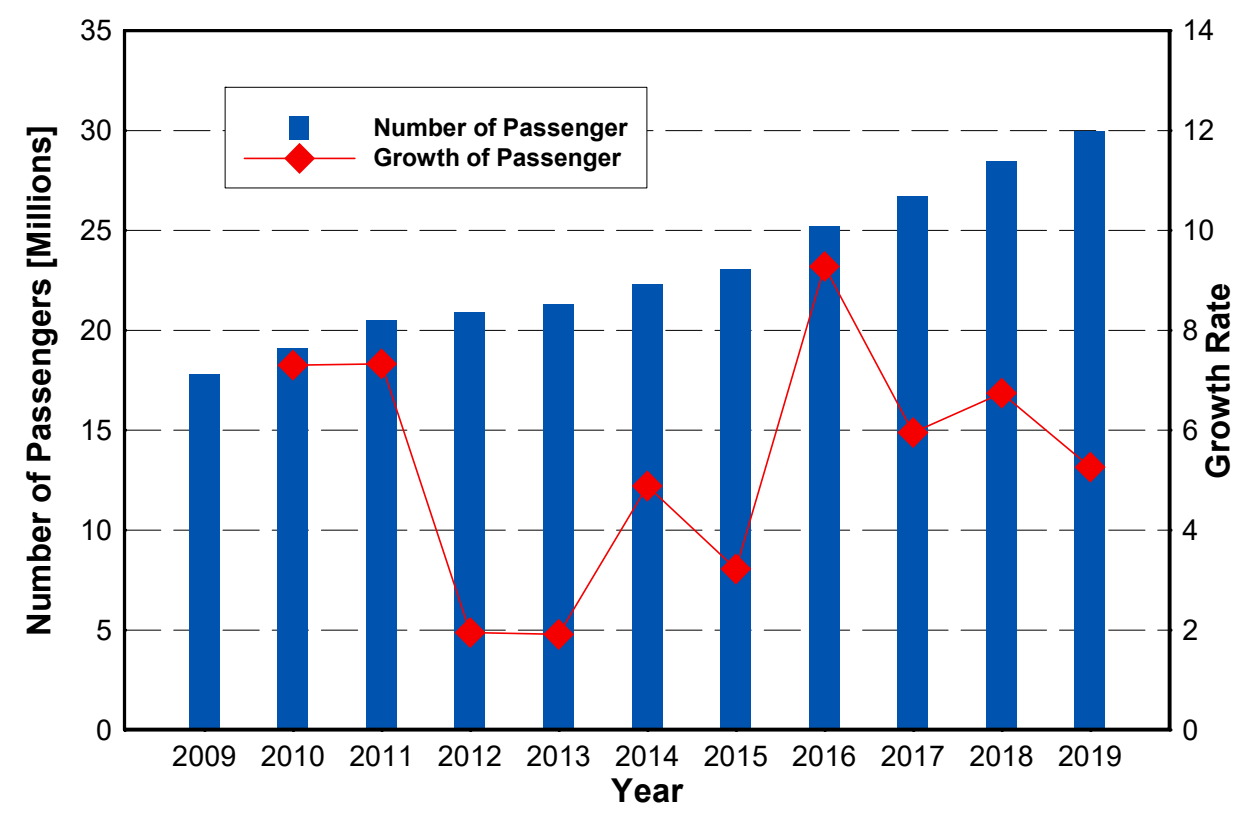

Figure 1. Cruise passenger growth worldwide 2009-2019.

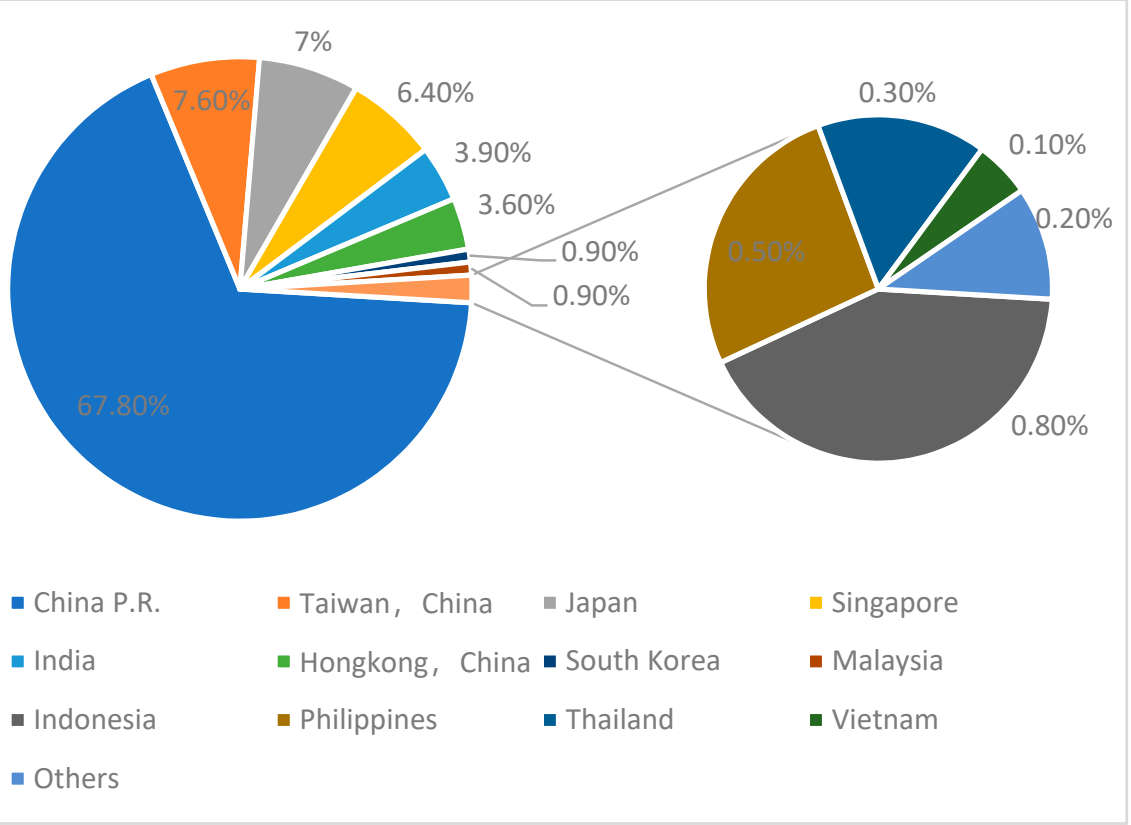

Figure 2. Share of Chinese cruise passengers in Asia (2019). 


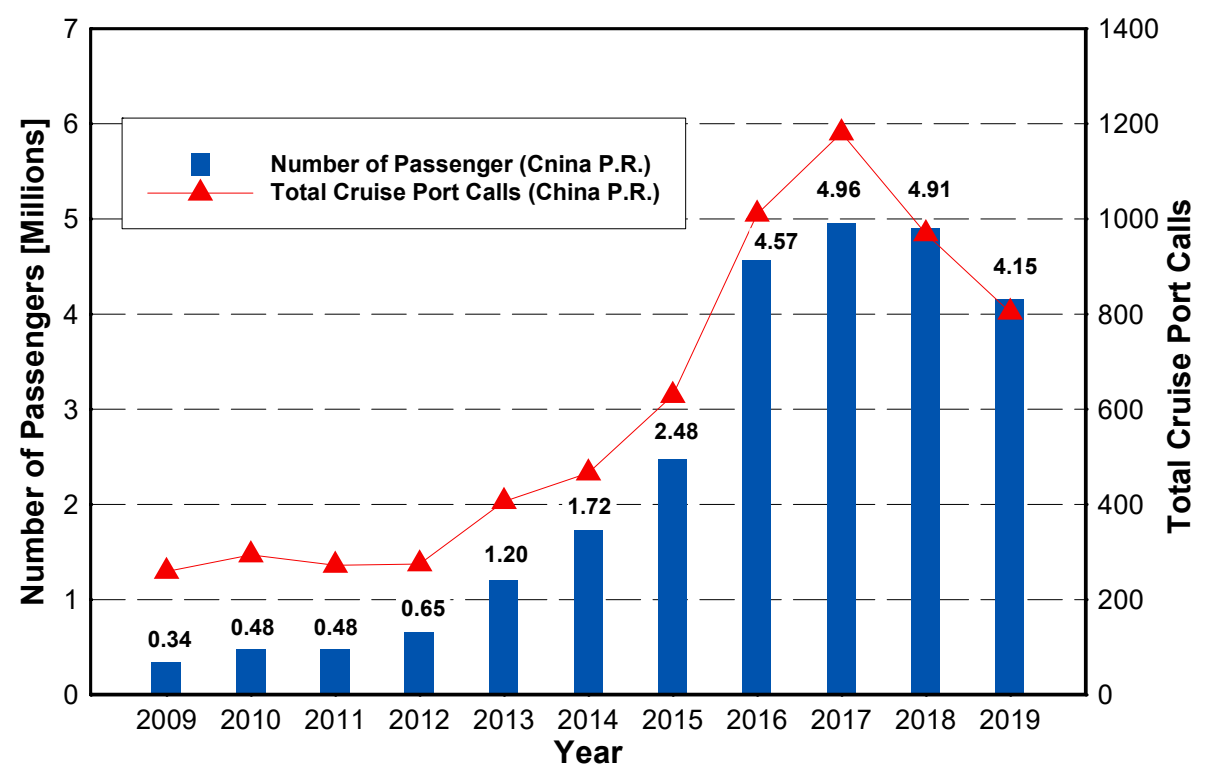

Figure 3. Passengers and port calls growth in China.

The rapid development of cruise tourism has also led to the development of cruise ports, terminals, and related cities. Cruise ports and terminals play a crucial part in attracting tourists in emerging cruise regions, and the development of ports and related cities has potential benefits [11]. China has 13 cruise ports, and the Shanghai Wusongkou cruise terminal has become the busiest international cruise home port in the Asia-Pacific region with 375 ports of call one year.

Not only in China, with the fast development of the cruise market, and the diversification of cruise products, new cruise destinations continue to emerge worldwide. A growing number of cruise ships offer trips to far-flung destinations, including Marine World Heritage (MWH) sites, in an effort to satisfy as many tourists as possible, which raises concerns about environmental protection from cruise ships [12].

In fact, cruise ships produce a wide variety of organic and inorganic wastes in the form of gases, liquids and solids. These wastes pose varying degrees of risk and harm to the environment [13]. The main types of pollution caused by cruise ships are the following:

- Water Pollution

Cruise water pollution mainly comes from blackwater and greywater. Blackwater is sewage from cruise ship toilets and medical facilities that contains harmful bacteria, pathogens, parasites and diseases. Greywater is wastewater from kitchen sinks, laundry, and other cleaning activities on ships, which may contain a variety of detergents, insecticides, and other toxic pollutants [14]. According to the U.S. Environmental Protection Agency, a cruise ship that holds 3000 people produces 150,000 gallons of sewage each week, which equates to more than a billion gallons of sewage produced by the industry each year [15].

- Air Pollution

Cruise ship emissions are mainly composed of $\mathrm{NO}_{x}, \mathrm{SO}_{x}$, and $\mathrm{CO}_{x}$ gases and suspended particles. The cheap, sulfur-rich fuels used by most cruise ships are 1000 times dirtier than road transport fuels [16]. A study measured particulate matter (PM) concentrations on the deck of four cruise ships and found that the PM on the decks was comparable to that measured in polluted cities [17].

- Solid Pollution

Solid waste includes glass, paper, cans, and plastics. The scale of the solid waste problems is staggering - about 1 billion kilograms of waste are dumped into the world's oceans each year [14]. According to statistics, $24 \%$ of the solid waste generated by ships 
globally comes from cruise ships [18]. Therefore, cruise ships face waste storage and management problems. Although a small amount of waste is disposed of ashore or recycled, most solids are incinerated on cruise ships, which can pose a threat to the marine environment.

If not properly handled and disposed of, these wastes, whether in air, water or solid form, may pose risks to ports, the urban environment, and even human health.

Studies have pointed out that the pollutants discharged by cruise ships could move toward the mainland and interact with and influence the coastal environment conditions [19]. In addition, as cruise ports are close to urban areas, the activities of a cruise ship at port can also have a negative influence on the environment of the whole city [20]. Since the number of cruise tourists has doubled in the past decade, and most cruise ships offer one-day or half-day touch down tours to coastal areas, a large number of visitors arriving in a short time can have a negative influence on the local environment [13].

Although various countries, including China, are promoting sustainable development of "Green Industries" through measures such as energy saving, emission reduction, and waste recycling, the current achievements are mainly obtained through passive responses to environmental problems [21].

According to the World Tourism Organization, the tourism industry must consider its current and future impacts on the economy, society, and environment, in addition to meeting its own needs, as well as those of tourists, the environment, and host countries, to ensure its long-term sustainability [22]. The cruise industry needs to balance economic interests with overall environmental impacts for sustainable activity. One of the primary challenges facing the cruise industry is dealing with natural and social environmental issues [23].

Therefore, in order to deal with the problems of environmental protection of cruise ships, this paper discusses from the perspective of law, taking China as an example to explore the application of Chinese laws and policies to solve these problems. Section 3 describes relevant laws, regulations, and policies related to environmental protection from cruise ships, Section 4 discusses the challenges in cruise environmental protection, and the conclusion is in Section 5.

\section{Methods}

Although there is a lot of literature on cruise pollution from the perspective of environmental science, there are few legal literatures on cruise environmental protection. The research method followed in this paper is classical legal methods. They are primarily desktop studies and analyses of major legal resources, including international conventions and Chinese laws and regulations related to cruise pollution management and prevention. They mainly include: The United Nations Convention on the Law of the Sea (hereafter referred to as UNCLOS), The International Convention for the Prevention of Pollution from Ships, 1973, as modified by the Protocol of 1978 relating thereto and by the Protocol of 1997 (hereafter referred to as MARPOL), The Marine Environment Protection Law of the People's Republic of China (Amendment 2017), Regulation on the Prevention and Control of Vessel-induced Pollution to the Marine Environment (2018 Revision), etc.

This paper outlines the laws and regulations related to environmental protection from cruise ships, conducts an analysis based on literature research, and answer research questions using legal resources. Combining the legal description with data of the cruise industry in China, environmental impacts, and practical challenges of environmental laws in China, the paper analyzes the hazards of cruise pollution and the necessity of waste treatment, clarifies the challenges facing cruise environmental protection at present. On the basis of the analysis, this paper emphasizes the importance of sustainable development for cruise tourism. 


\section{Applicable Laws and Regulations on Environmental Protection from Cruise}

\subsection{International Conventions}

There are two main international conventions related to cruise pollution, UNCLOS and MARPOL.

UNCLOS is often called the "constitution for the oceans". It provides a legal framework to be followed for all types of marine activities, including those related to the protection and sustainable use of oceans and their resources [24]. Part XII of UNCLOS emphasizes the protection and preservation of the marine environment.

For pollution caused by ships, Article 211 of the convention provides that states shall establish rules and standards to prevent, reduce, and control pollution of the marine environment from ships, while the standards should be consistent with Article 300 (Good Faith and Abuse of Rights). Article 218 is related to enforcement by port states, including investigations and judicial proceedings.

However, the provisions of this convention are broad. As the convention does not explicitly limit the exercising of the port state jurisdiction, there is still confusion about the scope and status of jurisdiction in both international and domestic laws [25].

As a specialized agency of the United Nations, the International Maritime Organization (IMO) is also the global regulator of shipping and, has the responsibility to prevent and control marine pollution by ships [26]. MARPOL was first adopted by the IMO in 1973 and amended over time. MARPOL is an international convention regulating the disposal of wastes generated by the normal operation of ships. It includes regulations for preventing and minimizing both accidental and operational pollution from ships and currently includes six technical annexes [27]:

Annex I-Regulations for the Prevention of Pollution by Oil

Annex II-Regulations for the Control of Pollution by Noxious Liquid Substances in Bulk Annex III-Prevention of Pollution by Harmful Substances Carried in Packaged Form Annex IV—Prevention of Pollution by Sewage from Ships

Annex V-Prevention of Pollution by Garbage from Ships

Annex VI—Prevention of Air Pollution from Ships

Details are given in Table 1 below.

These annexes provide an overall legal framework for achieving the goal of controlling pollutant emissions from ships. However, the convention cannot fully protect the marine environment from pollutant emissions, and states parties should actively formulate and implement domestic laws and regulations consistent with the convention. According to Article 4 of MARPOL, states parties should prohibit acts of environmental pollution and penalties should be adequate in severity to discourage violations of the convention. While states abide by the international convention, they enact more stringent domestic law themselves, and a domestic law should be considered valid as long as it does not conflict with the basic principle of the prescriptive jurisdiction [28]. In fact, as long as domestic rules do not conflict with general limits on prescriptive jurisdiction, then they can be more stringently implemented and enforced [29]. 
Table 1. Main contents of the MARPOL and its Annexes.

\begin{tabular}{|c|c|c|}
\hline $\begin{array}{l}\text { Types of } \\
\text { Pollution }\end{array}$ & Time in Force & Main Contents \\
\hline Oil Pollution & 1983 & $\begin{array}{l}\text { Oil tankers should be safely built and operated and are constructed to reduce } \\
\text { the amount of oil spilled in the event of an accident (Annex I). }\end{array}$ \\
\hline \multirow{2}{*}{ Sewage } & 2005 & $\begin{array}{c}\text { Governments are required to ensure the provision of adequate reception } \\
\text { facilities at ports and terminals for the reception of sewage, without causing } \\
\text { delay to ships. (Annex IV) }\end{array}$ \\
\hline & 2013 & $\begin{array}{l}\text { The discharge of sewage from passenger ships within a Special Area is } \\
\text { generally be prohibited except when the ship has in operation an approved } \\
\text { sewage treatment plant which has been certified by the Administration } \\
\text { (resolution MEPC.227(64)). }\end{array}$ \\
\hline Garbage & 1988 & $\begin{array}{l}\text { The discharge of all garbage is prohibited. Garbage includes all kinds of food, } \\
\text { domestic and operational waste, all plastics, cargo residues, incinerator ashes, } \\
\text { cooking oil, fishing gear and animal carcasses. (Annex V). }\end{array}$ \\
\hline \multirow{4}{*}{ Air Pollution } & 2005 & $\begin{array}{c}\text { The main air pollutants contained in ships exhaust gas are strictly controlled, } \\
\text { including } \mathrm{SO}_{\mathrm{x}} \text { and } \mathrm{NO}_{\mathrm{x}} \text {, the emissions of ozone depleting substances (ODS) } \\
\text { are prohibited. (Annex VI). }\end{array}$ \\
\hline & 2010 & $\begin{array}{l}\text { Emissions of } \mathrm{SO}_{\mathrm{x}}, \mathrm{NO}_{\mathrm{x}} \text { and particulate matter will be gradually reduced } \\
\text { globally, and the emission control zones (ECAs) will be established to reduce } \\
\text { emissions of those air pollutants further in designated sea areas. (Revised } \\
\text { MARPOL Annex VI). }\end{array}$ \\
\hline & 2013 & $\begin{array}{c}\text { Mandatory technical and operational energy efficiency measures are adopted } \\
\text { to significantly reduce the amount of CO2 emissions from international } \\
\text { shipping. (Resolution MEPC.203(62)). }\end{array}$ \\
\hline & 2018 & $\begin{array}{c}\text { Ships of } 5000 \text { gross tonnage and above are required to collect consumption } \\
\text { data for each type of fuel oil they use, as well as other, additional, specified } \\
\text { date including proxies for transport work. (Amendments to MARPOL } \\
\text { Annex VI). }\end{array}$ \\
\hline
\end{tabular}

\subsection{Laws and Regulations in China}

\subsubsection{Fundamental Laws}

China signed UNCLOS in 1982 and ratified the convention in 1996 [30]. In addition, since MARPOL and its six annexes have all been implemented in China, all cruise ships operating in China should, first, comply with MARPOL [31].

The Marine Environment Protection Law of the People's Republic of China (Amendment 2017) is widely accepted as the fundamental environmental law of the marine environment in China. It is formulated "in order to protect the marine environment and resources, prevent pollution damage, maintain ecological balance, safeguard human health and promote the development of marine programs" [32]. The law highlights the principle of "prevention first" and the authority and liability of administrative organizations as the subject of jurisdiction [33]. Article 96 provides that where there is a difference between the domestic legislation and an international convention that China has ratified, the convention should prevail unless China has made a reservation contrary to the convention. This clause again makes clear the inevitability of the application of international conventions.

Article 62 No vessel may, in violation of the provision of this Law, discharge oils, oil mixtures, wastes and other harmful substances into the sea areas under the jurisdiction of the People's Republic of China.

This clause prohibits the discharge of pollutants by ships. Chapter VIII of the law provides detailed provisions for how to prevent and control pollution damage to the marine environment caused by ships and their operations. 
Regulation on the Prevention and Control of Vessel-induced Pollution to the Marine Environment (2018 Revision) was enacted to prevent and control pollution of the marine environment caused by ships and their operations.

Article 2 This regulation shall apply to the prevention and control of pollution caused by vessels and the relevant operation to the sea areas of the People's Republic of China.

This clause makes it clear that the regulation does not exclude the application of cruise ships.

According to the regulation, the transport administrative department under the state council is responsible for the prevention and control of pollution of the marine environment caused by ships and the maritime administrative institutions are specifically responsible for the supervision and administration of the pollution [34].

\subsubsection{Other Regulations and Policies}

Other laws and regulations on the prevention and control of pollution from ships shall also apply to legal issues related to cruise ships. The detailed information can be found in Table 2 below.

Table 2. Main contents of relevant regulations.

\begin{tabular}{|c|c|c|c|}
\hline Name & Time in Force & Chapter/Section & Main Contents \\
\hline $\begin{array}{c}\text { Law of the People's Republic of } \\
\text { China on Prevention and Control } \\
\text { of Water Pollution }\end{array}$ & 2017 & $\begin{array}{c}\text { Chapter IV } \\
\text { Section } 5 \text { Prevention and Control } \\
\text { of Water Pollution from Vessels }\end{array}$ & $\begin{array}{l}\text { The discharge of oil-bearing wastewater or } \\
\text { domestic sewage from ships shall comply with } \\
\text { the standards for pollutant discharge by ships. } \\
\text { (Article 59) } \\
\text { Ports, docks and relevant institutions shall have } \\
\text { adequate facilities for receiving pollutants and } \\
\text { wastes from ships. (Article 61) }\end{array}$ \\
\hline $\begin{array}{l}\text { Atmospheric Pollution Prevention } \\
\text { and Control Law of the People's } \\
\text { Republic of China }\end{array}$ & 2018 & $\begin{array}{c}\text { Chapter IV } \\
\text { Section } 3 \text { Prevention and Control } \\
\text { of Pollution from Motor-driven } \\
\text { Vehicles and Vessels }\end{array}$ & $\begin{array}{l}\text { No Motor-driven Vessel may discharge } \\
\text { atmospheric pollutants in excess of the } \\
\text { standards. (Article 51) } \\
\text { Ocean-going vessels shall use ship fuel oil that } \\
\text { meet the requirements for the control of air } \\
\text { pollutants after docking at the port. (Article 63) }\end{array}$ \\
\hline $\begin{array}{l}\text { Administrative Provisions of the } \\
\text { People's Republic of China on the } \\
\text { Prevention and Control of Marine } \\
\text { Environmental Pollution by } \\
\text { Vessels and Their Operations }\end{array}$ & 2017 & All of the Chapters & $\begin{array}{l}\text { The discharge of refuse, sewage, waste gas and } \\
\text { other pollutants, as well as ballast water by ships } \\
\text { sailing or berthing in the sea areas under China's } \\
\text { jurisdiction shall comply with laws, regulations } \\
\text { and relevant standards, as well as the provisions } \\
\text { of the international conventions concluded or } \\
\text { acceded to by China. (Article 12) }\end{array}$ \\
\hline $\begin{array}{c}\text { Law of People's Republic of } \\
\text { China on Ports }\end{array}$ & 2018 & $\begin{array}{c}\text { Chapter IV Port Safety and } \\
\text { Supervision }\end{array}$ & $\begin{array}{l}\text { It is forbidden to discharge toxic and harmful } \\
\text { substances in excess of the prescribed standards } \\
\text { into port waters. (Article 37) }\end{array}$ \\
\hline
\end{tabular}

In addition, the Chinese government has issued various policies at state and local levels to support the development of the cruise industry to the maximum.

At the state level, the important developmental policies include Suggestions on Promoting the Development of China's Cruise Economy, jointly issued by 10 ministries of China and the National Cruise Tourism Development Overall Plan (2016-2025) issued by the national tourism administration. These policies cover cruise education, entry and exit of passengers, inspection and quarantine, tourism and accommodation service standards, and cruise operations and shipbuilding, but pollution control is not the main content of these policies [11].

At the local level, many coastal cities in China are racing to build cruise ports and formulate industrial policies. Many of them have also formulated measures for the prevention and control of pollution from cruise ships in ports, but most of these measures are simple duplicates of national laws, which cannot satisfactorily deal with the actual problems of pollution from cruise ships in ports [35]. 


\section{Challenges for Environmental Protection from Cruise in China}

\subsection{The Convenience Flag of Cruise Ships}

The flag state jurisdiction is one of the fundamental principles of maritime law, according to UNCLOS:

Article 91 Every State shall fix the conditions for the grant of its nationality to ships, for the registration of ships in its territory, and for the right to fly its flag. Ships have the nationality of the State whose flag they are entitled to fly. There must exist a genuine link between the State and the ship.

Article 94 Every State shall effectively exercise its jurisdiction and control in administrative, technical and social matters over ships flying its flag.

A ship is said to be flying convenience flag if it is registered in a foreign country to reduce operating costs or avoid government regulations. Flag of convenience refers to the purpose of maximizing private income and minimizing private cost by avoiding regulations after the shipping company chooses the ship's flag [36].

Although flag states have exclusive jurisdiction over flagged ships on the high seas, the flag states and ships tend to lack a genuine link. In fact, UNCLOS attempts to limit the convenience flag behavior with the genuine link and urges flag states to fulfill their responsibility of ship management, but this does not make any real difference [37]. The convenience flag has affected the legal framework for the maritime trade in recent decades. Flying foreign state flags is a common phenomenon in the global shipping industry, and it has adverse effects on the shipping order: most of the ships registered in convenience flag countries cannot meet safe operation standards [38].

Most cruise companies register their ships under a convenience flag, which means that ship-owners register ships outside their own countries and that the flag states cannot effectively supervise the ownership, safety system, and quality of the crew, resulting in a vacuum in the supervision of the convenience flag [39].

Using a convenience flag further complicates the legal issues caused by cruise ships. In China, the fee of a cruise home port mainly includes government expenses and terminal enterprise expenses. The comprehensive charges for a domestic port call are $3 \sim 5$ times higher than those in the United States and 2 3 times higher than those in Europe. Even if a cruise ship is registered in China, it still has to pay taxes, including corporate income tax, vehicle and ship usage tax, and stamp duty, accounting for $30 \%$ of the total cost [40]. China tried to encourage its ships to register locally by introducing duty-free registration policies, but it was considered a complete failure [41]. As a result, there is still no Chinese nationality cruise ship.

\subsection{Jurisdiction of Cruise Pollution Cases}

The jurisdiction of the flag state is not entirely exclusive, with the proliferation of a convenience flag and the increasing complexity of maritime activities, some of the flag state's jurisdiction began to be weakened by other jurisdictions [42]. In the area of pollution prevention and control, the jurisdiction of port states and coastal states is expanding. MAPROL affirms the right of coastal and port states to exercise jurisdiction over ships of other nationalities. The coastal state jurisdiction extends to maritime zones such as the exclusive economic zone and is closely connected with the right of innocent passage, while the port state jurisdiction is concerned only with territorial jurisdiction.

According to the MARPOL, a ship required to hold a certificate in accordance with the provisions of the regulation is subject, while in the ports or offshore terminals under the jurisdiction of a Party, to inspection by officers duly authorized by that Party [27]. Any violation of the requirements of the present Convention within the jurisdiction of any Party to the Convention shall be prohibited and sanctions shall be established therefor under the law of that Party [27]. As the wording suggests, the port state still exercises the port state jurisdiction for foreign ships visiting port and, inspects visiting ships regardless of whether their flag state is a party to the convention [28]. 
Meanwhile, since MARPOL does not explain "within the jurisdiction of any Party" and UNCLOS had not been adopted when MARPOL was adopted, the expression here is not clear. According to Annexes IV and V, some discharges may be within the territorial sea, while others are outside. For jurisdiction over extraterritorial areas, Article 220 of UNCLOS issued the enforcement by coastal states, this is extended territorial jurisdiction, which should be consistent with the competence enjoyed by states in a particular maritime area. A state can exercise compulsory jurisdiction in its ports over violations of its laws only when the state has adopted its laws within the exclusive economic zone in accordance with the provisions of UNCLOS [28]. The port state needs to exercise its jurisdiction reasonably, with due regard for the interests of affected states and individuals [43].

Most cruise ships sail on the high seas, and once pollution case occurs, the pollution case will involve the issue of whether China has jurisdiction [44]. Since there is no cruise ship with the Chinese flag in China at present, it will be difficult for China to exercise the flag state jurisdiction over cruise ships.

However, in 2016, China's Supreme People's Court issued a judicial interpretation to clarify the jurisdiction. According to the interpretation, marine pollution disputes in inland waters, territorial seas, contiguous zones and exclusive economic zones will be under the jurisdiction of China's maritime courts [45].

In fact, the focus of the provisions is not the jurisdiction of pollution by ships but by fishing industry and China's maritime rights and interests. The enforcement measures issued here are intrusive, such as arrest, detention, and confiscation. China's jurisdiction has been moderately expanded through this [46]. This interpretation, which avoids weak enforcement on the high seas and the ineffective flag states, is a kind of "extraterritoriality" [47].

In other words, China can take direct enforcement action as long as the pollution occurs with its jurisdiction, while it refers the case to the flag state when the pollution occurs outside China's jurisdiction or when jurisdiction is uncertain. However, these procedures require a lot of coordination between government agencies and huge funding, and the response rate from flag states is low [48]. In addition, to what extent is port jurisdiction limited by international law? There is still confusion over the scope and status of jurisdiction [25].

\subsection{Incomplete Legislation}

\subsubsection{Narrow Scope of the Legal Protection of Cruise Problems}

Although China has passed marine environmental protection laws and regulations, the specific provisions are not perfect, and implementation is insufficient [49]. To a large extent, the current Marine Environment Protection Law still retains the legal system based on the concept of "prevention first", and the penalties for violations are not strong enough [50].

Whether international conventions or Chinese laws, most of the current laws focus on oil pollution from ships, and there are few regulations on water pollution such as blackwater and greywater. In the case of China, the current laws fail to effectively connect, whether the case is related to pollutant reception or facility supervision, and there are still many problems in practice.

In terms of environmental protection from cruise ships, there is no comprehensive law that covers cruise ship pollution in China. The prevention and control of cruise pollution can only get fundamental legal support from some provisions in related laws and regulations, and the legislation fails to take into account the severity of cruise pollution.

\subsubsection{Lack of Provisions for Land and Ports}

The land and the sea should be closely linked, but for marine environmental laws and regulations in China, they are not united [51]. In other words, most laws and regulations control marine pollution from the perspective of ships, ignoring port liabilities, pollutant acceptance, and other issues. 
In fact, the facilities and arrangements for receiving pollutants at port are inadequate. For example, according to the Administrative Provisions of the People's Republic of China on the Prevention and Control of Marine Environmental Pollution by Vessels and Their Operations:

Article 18 When receiving pollutants from ships, a pollutant receiving institutions shall issue a pollutant receiving document to the ship, which shall be signed and confirmed by the ship master.

Under this provision, if a ship submits relevant discharge documents, the authorities assume that the pollutants have been received, and there is no specific practice for investigation or specific pollutant collection, Chinese laws do not regulate the qualifications of the receiving institutions. If, the institutions do not have the ability to receive pollutant, this not only cannot effectively prevent cruise pollution, but also may cause secondary pollution on land.

Under the current management system in China, maritime management organizations are required to pass proposals on pollutant reception facilities before the reconstruction of port facilities, while the planning and construction of ports and their facilities is still under the administration of ports [52]. This results in slow progress in the development of port facilities.

\subsubsection{Inadequate Supervision and Law Enforcement}

In terms of regulations, China is still in a situation of decentralized supervision by multiple departments [53]. According to the Marine Environment Protection Law, the authorities responsible for regulating pollution from ships include not only the maritime administration but also many national agencies such as the State Fisheries Administration and the Harbor Superintendency Administration [32]. Law enforcement is carried out by the Maritime Safety Administration in cooperation with the China Coast Guard. The supervision of multiple departments is not unified, and the Maritime Safety Administration is mostly responsible for law enforcement, with unclear division of labor and chaotic law enforcement [54].

In addition to the imperfect regulatory system, although the law clearly stipulates that all individuals have the obligation to monitor and report any acts causing pollution damage to the marine environment [32], the provision is not mandatory and there is no doubt that it is not enough to rely only on individuals to report and supervise the pollution behavior of cruise ships.

\section{Conclusions}

With the fast development of the cruise industry, the problem of cruise pollution should be considered. Only a responsible industry can provide more sustainable long-term benefits [55]. The environmental impact of cruise ships is far greater than that of ordinary passenger ships, but pollution prevention and control in both cases is similar. At present, the challenges in environmental protection from cruise ships are mainly related to three aspects: the convenience flag of cruise ships, the jurisdiction of cruise pollution cases, and the incomplete legislation.

The use of a convenience flag adds to the complicated legal issues for cruise ships, as many of them are registered abroad to reduce operating costs or avoid government regulations. Under such circumstances, it is difficult for countries to exercise the flag state jurisdiction over cruise ships. In addition, the ranges of port state jurisdiction and coastal state jurisdiction are expanding, although some of the legal definitions are still unclear. At present, the prevention and control of cruise pollution can only get some fundamental legal support from several relevant laws and regulations, while ignoring port liability, pollutant acceptance, and other issues. In terms of supervision, decentralized supervision by multiple departments is not conducive to the prevention and control of cruise pollution.

For China, due to the late start of marine environmental protection legislation, most of the current domestic legislation comes from international conventions and the advanced 
experience of other countries, and cruise environmental legislation is insufficient. This may create obstacles in the sustainable development of the cruise industry. The whole international community, including China, should focus on the environmental problems caused by cruise ships and legally solve them, so as to promote better development of the cruise industry.

Author Contributions: Conceptualization, Y.Y. and Y.S.; methodology, Y.Y.; data curation, Y.Y. and Y.S.; writing — original draft preparation, Y.Y.; writing—review and editing, Y.S.; visualization, Y.S.; supervision, Y.S.; project administration, Y.Y.; funding acquisition, Y.Y. and Y.S. Both authors have read and agreed to the published version of the manuscript.

Funding: This research was funded by Social Science Foundation of Shandong Province, grant number 19CQXJ02.

Institutional Review Board Statement: Not applicable.

Informed Consent Statement: Not applicable.

Data Availability Statement: Not applicable.

Conflicts of Interest: The authors declare no conflict of interest.

\section{References}

1. World Tourism Organization (UNWTO). Special report: Cruise tourism current situation and trends in Asia and the Pacific. UNWTO 2012, 25, 28-31.

2. Radic, A. Towards an understanding of a child's cruise experience. Curr. Issues Tour. 2017, 22, 237-252. [CrossRef]

3. Tur, A.; Azorín, N.; Parreno, R. Estimating the impact of cruise tourism through regional input-output tables. Int. J. Tour. Hosp. Res. 2019, 30, 235-245.

4. 2020 State of The Cruise Industry Outlook Report. Available online: https:/ / cruising.org/news-and-research/research/2019 / december/state-of-the-cruise-industry-outlook-2020 (accessed on 25 March 2021).

5. China Cruise \& Yacht Industry Association. 2019 China Cruise Industry Development Report, 1st ed.; Tourism Education Press: Beijing, China, 2019; pp. 121-168.

6. Jiao, Y.; Dulebenets, M.A.; Lau, Y.-Y. Cruise Ship Safety Management in Asian Regions: Trends and Future Outlook. Sustainability 2020, 12, 5567. [CrossRef]

7. Lau, Y.-Y.; Yip, T.L. The Asia cruise tourism industry: Current trend and future outlook. Asian J. Shipp. Logist. 2020, 36, 202-213. [CrossRef]

8. Hung, K.; Wang, S.; Guillet, B.D.; Liu, Z. An overview of cruise tourism research through comparison of cruise studies pub-lished in English and Chinese. Int. J. Hosp. Manag. 2019, 77, 207-216. [CrossRef]

9. Guo, X. Explore China cruise development of future by innovation and reform. China Ports 2019, 1, 28-30.

10. 2019 Statistical Bulletin on the Development of the Transport Industry. Available online: http://xxgk.mot.gov.cn/jigou/zhghs/ 202005/t20200512_3374322.html (accessed on 15 March 2020).

11. Sun, X.; Feng, X.; Gauri, D.K. The cruise industry in China: Efforts, progress and challenges. Int. J. Hosp. Manag. 2014, 42, 71-84. [CrossRef]

12. Cerveny, L.K.; Miller, A.; Gende, S. Sustainable Cruise Tourism in Marine World Heritage Sites. Sustainability $2020,12,611$. [CrossRef]

13. Carić, H.; Mackelworth, P. Cruise tourism environmental impacts-The perspective from the Adriatic Sea. Ocean Coast. Manag. 2014, 102, 350-363. [CrossRef]

14. Protect our Seas from Cruise Pollution. Available online: http://www.wiinom.us.edu.pl/sites/default/files/WSPOLPRACA/ Art_2007_02.pdf (accessed on 1 March 2021).

15. 2019 Cruiseship Report Card. Available online: https:// foe.org/cruise-report-card/ (accessed on 1 March 2021).

16. Guerra, R.; Moreno, M.; García, C.; Cacho, N. Prediction of the impact on air quality of the cities receiving cruise tourism: The case of the Port of Barcelona. Heliyon 2019, 5, e01280. [CrossRef] [PubMed]

17. An Investigation of Air Pollution on the Decks of 4 Cruise Ships. Available online: https://www.researchgate.net/publication/ 330666991 (accessed on 2 March 2021).

18. Brida, J.G.; Zapata, S. Cruise tourism: Economic, socio-cultural and environmental impacts. Int. J. Leis. Tour. Mark. 2010, 1, 205. [CrossRef]

19. Lee, H.; Park, D.; Choo, S.; Pham, H.T. Estimation of the Non-Greenhouse Gas Emissions Inventory from Ships in the Port of Incheon. Sustainability 2020, 12, 8231. [CrossRef]

20. Perdiguero, J.; Sanz, A. Cruise activity and pollution: The case of Barcelona. Transp. Res. Part D Transp. Environ. $2020,78,102181$. [CrossRef] 
21. Wu, X.; Chen, H.; Min, J. Sustainability assessment of cruise-industry development: A case study of Xiamen, China. Policy Manag. 2021, 48, 213-224. [CrossRef]

22. Sustainable Development. Available online: https://www.unwto.org/sustainable-development (accessed on 1 March 2021).

23. Dowling, R.K.; Vasudavan, T. Cruising in the New Millennium. Tour. Recreat. Res. 2000, 25, 17-27. [CrossRef]

24. Achieving SDG 14: The Role of the United Nations Convention on the Law of the Sea. Available online: https://www.un.org/ en/chronicle/article/achieving-sdg-14-role-united-nations-convention-law-sea (accessed on 2 March 2021).

25. Ryngaert, C.; Ringbom, H. Introduction: Port State Jurisdiction: Challenges and Potential. Int. J. Mar. Coast. Law 2016, 31, 379-394. [CrossRef]

26. Introduction to IMO. Available online: https:/ / www.imo.org/en/About/Pages/Default.aspx (accessed on 1 March 2021).

27. International Convention for the Prevention of Pollution from Ships (MARPOL). Available online: https://www.imo.org/en/ About/Conventions/Pages/International-Convention-for-the-Prevention-of-Pollution-from-Ships-(MARPOL).aspx (accessed on 1 March 2021).

28. Marten, B. Port State Jurisdiction, International Conventions, and Extraterritoriality: An Expansive Interpretation. In Jurisdiction over Ships: Post-UNCLOS Developments in the Law of the Sea; Victoria University of Wellington School of Law: Wellington, New Zealand, 2014.

29. Johnson, L.S. Johnson Coastal State Regulation of International Shipping, 1st ed.; Oceana Publications Inc.: Dobbs Ferry, NY, USA, 2014; pp. 43-44.

30. Standing Committee of the National People's Congress. Available online: http://www.npc.gov.cn/wxzl/gongbao/2000-12/16 / content_5003571.htm (accessed on 5 March 2021).

31. The Announcement of China's Accession to the Convention and Its Annexes can be Found on the Government Website of the Ministry of Transport of China. Available online: http:/ / www.mot.gov.cn/ (accessed on 5 March 2021).

32. Marine Environment Protection Law of the People's Republic of China. Available online: http://www.npc.gov.cn/zgrdw/npc/ zfjc/zfjcelys/2018-11/12/content_2065782.htm (accessed on 3 March 2021).

33. Fu, Q. Research on Legislative Issues in Safeguarding China's Marine Economic Rights. Law Sci. Mag. 2020, 9, 96-103.

34. Regulation on the Prevention and Control of Vessel-induced Pollution to the Marine Environment. Available online: http: //www.mee.gov.cn/ywgz/fgbz/xzfg/201805/t20180516_440446.shtml (accessed on 5 March 2021).

35. Take Shanghai, China's Largest Cruise Home Port, as an Example. Available online: https:/ /www.shanghai.gov.cn/ (accessed on 3 March 2021).

36. Metaxas, B.N. Flags of convenience. Mar. Policy 1981, 5, 52-66. [CrossRef]

37. Sloane, R.D. Breaking the genuine link: The contemporary international legal regulation of nationality. Harv. Int. Law J. 2009, 50, 8-27.

38. Fossen, A.V. Flag of Convenience and Global Capitalism. Int. Crit. Thought 2016, 6, 359-377. [CrossRef]

39. Nanda, V.P. U.S. Perspective on the Legal Aspects of Cruises. Am. J. Comp. Law 2018, 66, 213-242.

40. Wang, H. Annual Report on China's Cruise Industry (2019), 1st ed.; Social Sciences Academic Press: Beijing, China, 2019; pp. 60-65.

41. Chen, J.; Li, K.X.; Liu, X.; Li, H. The development of ship registration policy in China: Response to flags of convenience. Mar. Policy 2017, 83, 22-28. [CrossRef]

42. Zhang, X.L.; Zheng, L. Theory of "the flag state center doctrine" deviation in the international maritime jurisdiction. Law Rev. 2010, 6, 69-76.

43. Benvenisti, E. Sovereigns as Trustees of Humanity: On the Accountability of States to Foreign Stakeholders. Am. J. Int. Law 2013, 107, 295-333. [CrossRef]

44. Guo, P. Consideration of Marine environmental pollution by cruise legal problems. In Proceedings of the Chinese Society of Environment and Resources Law, Baoding, China, 25-27 August 2017; pp. 327-333. (In Chinese).

45. Provisions of the Supreme People's Court on Several Issues concerning the Trial of the Relevant Cases Occurring in Sea Areas under the Jurisdiction of China. Available online: http:/ / www.court.gov.cn/fabu-xiangqing-24261.html (accessed on 3 March 2021).

46. Liu, H.R. The Significance of Marine Related Judicial Interpretations by the Supreme People's Court from the Perspective of the Law of the Sea. J. Ocean Univ. China 2017, 2, 1-4.

47. Kopela, S. Port-State Jurisdiction, Extraterritoriality, and the Protection of Global Commons. Ocean Dev. Int. Law 2016, 47, 89-130. [CrossRef]

48. Cruise Ship Pollution: Background, Laws and Regulations, and Key Issues. Available online: https:/ / digital.library.unt.edu/ark: /67531/metadc93985/m1/1/high_res_d/RL32450_2008Jul01.pdf (accessed on 5 March 2021).

49. Xu, X. Marine Environmental Protection Law, 1st ed.; Law Press: Beijing, China, 2020; pp. 166-175.

50. Zhang, H.W. Review and prospect of the development of 'Marine Environmental Protection Law of the People's Republic of China'. Environ. Sustain. Dev. 2020, 4, 79-84.

51. Sun, J.T.; Zhou, L.P. China's Marine Environmental Governance in the New Normal Context. J. Ocean Univ. China 2021, 1, 32-39. [CrossRef]

52. Yang, Z.J. Extraction combined with MARPOL convention adopted vessel garbage pollution prevention. China Water Transp. 2011, 11, 47-48. 
53. Lu, J.H.; Jiang, C.Y. Maine Environment Enforcement in China: History, Problems and Suggestions. J. Zhejiang Ocean Univ. 2019, $6,32-35$

54. Li, L. On Reform and Development Goal of Maritime Law Enforcement Forces in China. J. China Marit. Polic. Acad. 2018, 2, 1-10.

55. Klein, R.A. Responsible Cruise Tourism: Issues of Cruise Tourism and Sustainability. J. Hosp. Tour. Manag. 2011, 18, 107-116. [CrossRef] 